DETERRENCE AND DEFENCE IN A

POST-NUCLEAR WORLD 
Also by Gary L. Guertner

THE LAST FRONTIER: An Analysis of the Strategic Defence Initiative (co-author) 


\section{Deterrence and Defence in a Post-Nuclear World}

Gary L. Guertner

Director of Studies

Strategic Studies Institute

US Army War College 
Softcover reprint of the hardcover 1st edition 1990

All rights reserved. No reproduction, copy or transmission of this publication may be made without written permission.

No paragraph of this publication may be reproduced, copied or transmitted save with written permission or in accordance with the provisions of the Copyright, Designs and Patents Act 1988, or under the terms of any licence permitting limited copying issued by the Copyright Licensing Agency, 33-4 Alfred Place, London WC1E 7DP.

Any person who does any unauthorised act in relation to this publication may be liable to criminal prosecution and civil claims for damages.

First published 1990

Published by

THE MACMILLAN PRESS LTD

Houndmills, Basingstoke, Hampshire RG21 2XS

and London

Companies and representatives

throughout the world

British Library Cataloguing in Publication Data

Guertner, Gary L.

Deterrence and Defence in a Post-Nuclear World.

1. Warfare. Deterrence

I. Title

$355^{\prime} .0217$

ISBN 978-1-349-11450-4 ISBN 978-1-349-11448-1 (eBook)

DOI 10.1007/978-1-349-11448-1 
For Sally, Brandon and Megan 


\section{Contents}

List of Figures, Maps and Tables ix

Preface and Acknowledgements $\quad \mathrm{x}$

Glossary xii

Introduction 1

1 Obstacles To Conventional Deterrence 7

Flexible Response in Europe 9

Convergence of Flexible Response and Forward 13 Defense

The American Efforts To Structure Flexible 14

Response

The Requirements For Conventional Deterrence 18

2 Deterrence Soviet Style 34

Offensive Defense: Soviet Style 35

Stalin's Conventional Emphasis: Back To The 39 Future?

The Legacy of Stalin 42

Khrushchev: Strategic Bluff or Peripheral 45

Strategy?

The Brezhnev Period: The Origins of Flexible 50

Options

Flexible Response Since Brezhnev 56

The Shrinking Soviet Nuclear Umbrella: Cover $\quad 61$

Thyself

'Reasonable Sufficiency': Revolution or Ruse? 64

$\begin{array}{ll}\text { Conclusions } & 71\end{array}$

3 Soviet Incentives for Conventional Deterrence 79

Strategic Implications of the Nationalities $\quad 85$

Implications For US Strategy $\quad 91$

4 Arms Control: Can We Make This Trip With the 97

Russians?

The Charges 106

The Evidence $\quad 110$ 
viii

The Military Significance Of Non-compliance Issues

Conclusions

5 Security in A Post-Nuclear World: The Unfinished 133 Agenda

Arms Control Strategy and Nuclear

Modernization: Shaping Deterrence Stability

Soviet Strategic Modernization After START

Shaping Strategy and Targeting Policies For

Deterrence Stability

Strategic Stability and Conventional Deterrence 


\section{List of Figures, Maps and Tables}

Map 1.1 Forward Defense Areas and Population in the FRG

Figure 2.1 Soviet Strategic Evolution-ICBMs

Table 2.1 Weapons Destroyed Under the Terms of the INF Treaty

Table 2.2 Summary of Soviet Doctrinal Evolution

Map 3.1 Union Republics of the USSR 81

$\begin{array}{lll}\text { Map } 3.2 \text { Ethnic Russian Regions of the USSR } & 82\end{array}$

Table 3.1 Shifting Population Trends 83

$\begin{array}{lll}\text { Map } & 3.3 \text { Areas of Ethnic Unrest Since Glasnost } & 87\end{array}$

Table 4.1 President's Reports to Congress on Soviet 107 Non-compliance

Table 4.2 Competing Images of Soviet

Table 4.3 Military Significance of Soviet Non-compliance

Figure 4.1 Weapon's Cycle and Verification

Figure 5.1 Dilemmas of Nuclear Deterrence 135

$\begin{array}{lll}\text { Table 5.1 US Offensive Modernization Options } & 139\end{array}$

Table 5.2 Strategic Evolution 153

Table 5.3 Stable and Unstable Strategic Postures 157

Table 5.4 Characteristics of US and Soviet Strategic 158 Forces

Map 5.1 Conventional Forces Europe (CFE) 164 Negotiations

Table 5.5 Strategy After Conventional Arms Control 


\section{Preface and}

\section{Acknowledgements}

A number of trends are moving the Soviet-American strategic relationship in new directions. My optimism about these trends is neither utopian nor does it match the inflated spirit of the Reykjavik Summit which briefly had heads of state flush with enthusiasm for a world with zero nuclear weapons. I see no prospects for a nuclearfree world. It is impossible to turn back the clock. Too many technical bridges have been burned along the way; what science has given us cannot be erased from our history. There are, however, political decisions, technological innovations, and revisions of military strategy that can move us to a higher plateau on which the West and its Soviet adversary may find fewer incentives for arms competition.

Mutual deterrence between the United States and the Soviet Union is a formidable task. The verities of nuclear deterrence constantly produce policy choices that have dramatic effects on strategic stability. Examples include how we modernize offensive nuclear forces, how we proceed with strategic defense technologies, and how we combine both efforts with arms control negotiations. American efforts to extend deterrence to West European allies have made the nuclear aspect of that process more complex and volatile. Extended deterrence requires flexible military options across the conflict spectrum. In the case of Europe, conventional forces reduce the dependence on the early use of nuclear weapons that might otherwise engulf that theater in a nuclear war, which, in turn, could escalate to intercontinental attack against Soviet and American territory. The coupling of conventional and nuclear forces is intended to prevent all levels of war. The arcane strategies which flow from extended deterrence attempt to establish credible links between American infantrymen in Germany and nuclear missile silos in North Dakota and Wyoming. The nature of that linkage in the future is a central theme of this book.

Research for the book began in early 1986. Many of the issues discussed here were previously debated with colleagues and students at the US Army War College where I served as Visiting Professor of Strategy, and at the US Arms Control and Disarmament Agency 
where I was scholar-in-residence in 1985 . Their respectful, but often healthy skepticism was a valued corrective. The RAND/UCLA Center for the study of Soviet International Behavior and the California State University, Fullerton, President's Foundation generously provided funds in support of research and writing. The book could not have been completed without their support. Conversely, there is one individual who deserves special recognition because he did everything in his power to delay the completion of the project. Mikhail Gorbachev's meteoric rise on the scene, bringing with him a revolution in military thinking, made it virtually impossible to close the manuscript. Extensive additions and rewriting were required in response to the Gorbachev phenomenon. But all revolutions eventually slow down or pause for consolidation. Whatever else the General Secretary of the Soviet Union may offer, I am satisfied that the book has captured the foundations on which future American relations with the Soviet Union and its European allies will grow.

The author wishes to thank many people who offered constructive comments on various portions of the manuscript: Robert Bresler, Dan Caldwell, Otto Chaney, Greg Govan, David Hansen, David Jablonsky, Robert Kennedy, Michael Krepon, Arthur Lykke, Jack Mendelshon, Jay Mumford, John Scott, Donald Snow, John von Trott, Mark Walsh, and Dan Whiteside.

Parts of Chapter 4 were previously published in the Political Science Quarterly and appear here by permission. The views in this book are those of the author and should not be ascribed to the persons or organizations whose assistance is acknowledged above. 


\section{Glossary}

Arms Control - Explicit or implicit international agreements that govern the numbers, types, characteristics, deployment, and use of armed forces and armaments. (See also Arms Limitation and Disarmament.)

Arms Limitation - An agreement to restrict quantitative holdings of or qualitative improvements in specific armaments or weapons systems. (See also Arms Control.)

Assured Destruction - Ability to inflict unacceptable damage upon any single aggressor or combination of aggressors at any time during the course of a strategic nuclear exchange, even after absorbing a surprise first strike.

Containment - Measures to discourage or prevent the expansion of enemy territorial holdings and/or influence. Specifically, a US policy directed toward Communist expansion.

Controlled Counterforce War - War in which one or both sides concentrate on reducing enemy strategic retaliatory forces and take special precautions to minimize collateral casualties and damage.

Conventional Forces - Those forces capable of conducting operations using non-nuclear weapons.

Conventional Weapons - Non-nuclear weapons. Excludes all biological weapons, and generally excludes chemical weapons except for existing smoke and incendiary agents, and agents of the riot-control type.

Counterforce - A strategic concept which calls for the employment of strategic air and missile forces to destroy, or render impotent, military capabilities of an enemy force. (See also Countervalue.)

Countervalue - A strategic concept which calls for the destruction or neutralization of selected enemy population centers, industries, resources, and/or institutions which constitute the social fabric of a society. (See also Counterforce.)

Damage Limitation - Active and/or passive efforts to restrict the level and/or geographic extent of devastation during war. Includes counterforce actions of all kinds, as well as civil defense measures. Assumes a pre-emptive attack against enemy nuclear and/or Conventional Forces.

Deterrence - The prevention from action by fear of the consequences. Deterrence is a state of mind brought about by the existence 
of a credible threat of unacceptable counteraction; the denial of gains or the imposition of excessive costs.

Deterrence by Denial - War is averted so long as an aggressor is convinced that he cannot achieve his war objectives. This is accomplished by the ability to retaliate and/or conduct pre-emptive attacks against nuclear and conventional military forces (counterforce targeting).

Deterrence by Punishment-Similar to deterrence. Assumes a rational actor model of decision-making and mutual deterrence through assured retaliation. Assumes second-strike, countervalue targeting.

Disarmament - The reduction of armed forces and/or armaments as a result of unilateral initiatives or international agreement. (See also Arms Control and Arms Limitation.)

Doctrine - Fundamental principles by which the military forces or elements thereof guide their actions in support of national objectives. It is authoritative but requires judgment in application.

Escalation-An increase (deliberate or unpremeditated) in the scope, intensity, or geographic area of a conflict.

Essential Equivalence - A policy which stipulates a need for approximately equal capabilities, but does not demand numerical equality between the central strategic systems of the United States and the Soviet Union.

Finite Deterrence - The capability with a limited number of strategic weapons, to inflict a high level of damage (presumably unacceptable) on enemy population and industry, thus making nuclear war unthinkable.

Firebreak - A clear dividing point between conventional and nuclear weapons.

First-Strike - The first offensive move of a war. As applied to general nuclear war, it implies the ability to eliminate effective retaliation by the opposition. (See also Second-Strike.)

First-Strike Capability - The possession of sufficient nuclear weapons to eliminate the retaliatory forces of the attacked nations. It does not only mean the act of striking first.

First Use - The initial employment of specific military measures, such as nuclear weapons, during the conduct of a war. A belligerent could execute a second strike in response to aggression, yet be the first to employ nuclear weapons. (See also First-Strike.)

Flexible Response - A strategy predicted on meeting aggression at an appropriate level or place with the capability of escalating the level of 
conflict if required or desired.

Forward Defense - A strategy concept which calls for containing or repulsing military aggression as close to the original line of contact as possible so as to defend the entire territory of a nation or alliance. Graduated Deterrence - A range of power that inhibits, or deals effectively with aggression at all levels of conflict. (See also Deterrence and Mutual Deterrence.)

Hard Target - A target protected to some significant degree against the blast, heat and radiation effects of nuclear explosions of particular yields. (See also Soft Target.)

Launch-on-Warning - Use of strategic weapons in a retaliatory strike upon notification or belief that an enemy has launched a strategic attack but before the enemy weapons have actually struck friendly territory.

Launch-Under-Attack - Use of strategic weapons in a retaliatory strike upon notification or belief that an enemy has launched a strategic attack and after enemy weapons have struck friendly territory.

Limited War - A war in which one or more of the belligerents voluntarily exercise restraints, for example, on the type of weapons used, the geographic limits in which the war is conducted, targets, and/or objectives.

Massive Retaliation - The act of countering aggression of any type with tremendous destructive power; particularly a crushing nuclear response to any provocation deemed serious enough to warrant military action.

Mutual Deterrence - A stable situation in which two or more countries or coalitions of countries are inhibited from attacking each other because the casualties and/or damage resulting from certain retaliation would be unacceptable. (See also Deterrence.)

Nuclear Non-proliferation - Arms control measures designed to prevent the acquisition of nuclear weapons and delivery means by nations that do not have a nuclear capability. (See also Nuclear Proliferation.)

Nuclear Parity - A condition at a given point in time when opposing forces possess nuclear offensive and defensive systems approximately equal in overall combat effectiveness.

Nuclear Proliferation - The process by which one country after another comes into possession or control of nuclear weapons. (See also Nuclear Non-proliferation.) 
Overkill - Destructive capabilities in excess of those required to destroy specified targets and/or attain specific security objectives. Parity - A condition in which opposing forces possess capabilities of certain kinds that are approximately equal in overall effectiveness. (See also Sufficiency.)

Pre-emptive Attack - An attack initiated on the basis of incontrovertible evidence that an enemy attack is imminent.

Preventive War - A war initiated in the belief that armed conflict, while not imminent, is inevitable, and that to delay would involve greater risk. (See also Pre-emptive War.)

Second-Strike - A strategic concept which excludes pre-emptive and preventive actions before the onset of a war. After an aggressor initiates hostilities, the defender retaliates. In general nuclear war, this implies the ability to survive a surprise first-strike and respond effectively. (See also First-Strike.)

Second-Strike Capability - An essentially invulnerable nuclear force that can survive an enemy-initiated strike and still retaliate causing unacceptable damage to the enemy.

Soft Target - A target not protected or with limited protection against the blast, heat, and radiation produced by nuclear explosions or particular yields. (See also Hard Target.)

Strategic Forces - All combat forces, particularly long-range nuclear delivery systems, designed primarily for offensive strategic purposes. Strategic Stability - A condition of the military balance that, in a crisis, offers the Soviet Union no incentive to initiate a nuclear attack. Neither is the United States under pressure to do so. By contrast, strategic instability would be a condition in which either the United States or the Soviet Union (or both) believed that victory could be achieved and defeat averted only by striking the other side pre-emptively.

Strategy - The art and science of developing and using political, economic, psychological, and military forces as necessary during peace and war, to afford the maximum support to policies, in order to increase the probabilities and favorable consequences of victory and to lessen the chances of defeat.

Sufficiency-A force planning concept which calls for adequate military force to deter attack or to prevent coercion, without costly or wasteful excess capability. (See also Parity and Overkill.)

Threshold - An intangible line separating different kinds and levels of warfare, generally the separation between nuclear and non-nuclear 
xvi

Glossary

warfare. The greater the reluctance to use nuclear weapons, the higher the threshold.

Triad - The term used in referring to the basic structure of the US strategic deterrent force. It is comprised of land-based ICBMs, the strategic bomber force, and the Trident/Poseidon submarine fleet. These constitute the US strategic or central systems. 